\title{
Intergrowth of Orbignyella germana Bassler, 1911 (Bryozoa) and Lambelasma carinatum Weyer, 1993 (Rugosa) in the pelmatozoan- bryozoan-receptaculitid reefs from the Late Ordovician of Estonia
}

\author{
Olev Vinn, Ursula Toom, and Andrej Ernst
}

\begin{abstract}
The earliest known rugosan-bryozoan intergrowth is reported from the early Katian of Estonia. A specimen of Orbignyella germana Bassler, 1911, from pelmatozoan-bryozoan-receptaculitid reefs of the Vasalemma Formation shows intergrowth with rugosans Lambelasma carinatum Weyer, 1993. The morphology of the bryozoan colony does not show any malformations or changes in zooid size near the embedded rugosans. It is likely that intergrowth between $L$. carinatum and $O$. germana was purely accidental. Relatively high population densities and restricted space for growth in the reef may have caused this intergrowth. Rugosans may have benefitted from this association in achieving a stable substrate in shallow and hydrodynamically active waters of the reef environment, whereas bryozoans obviously used corals as a substrate. Lambelasma may have been especially prone for intergrowth with bryozoans as it participates in three associations in the Late Ordovician of Estonia.
\end{abstract}

Olev Vinn. Department of Geology, University of Tartu, Ravila 14A, 50411 Tartu, Estonia; olev.vinn@ut.ee Ursula Toom. Department of Geology, Tallinn University of Technology, Ehitajate tee 5, 19086 Tallinn, Estonia; ursula.toom@ttu.ee

Andrej Ernst. Institut für Geologie, Universität Hamburg, Bundesstr. 55, 20146 Hamburg, Germany;

Andrej.Ernst@uni-hamburg.de

Keywords: Intergrowth; symbiosis; rugosans; bryozoans; Katian; Baltica

Submission: 13 September 2017 Acceptance: 30 January 2018

\footnotetext{
Vinn, Olev, Toom, Ursula, and Ernst, Andrej. 2018. Intergrowth of Orbignyella germana Bassler, 1911 (Bryozoa) and Lambelasma carinatum Weyer, 1993 (Rugosa) in the pelmatozoan-bryozoan-receptaculitid reefs from the Late Ordovician of Estonia. Palaeontologia Electronica 21.1.4A 1-7. https://doi.org/10.26879/818 palaeo-electronica.org/content/2018/2134-rugosan-bryozoan-intergrowth

Copyright: February 2018 Palaeontological Association.

This is an open access article distributed under the terms of Attribution-NonCommercial-ShareAlike 4.0 International (CC BY-NC-SA 4.0), which permits users to copy and redistribute the material in any medium or format, provided it is not used for commercial purposes and the original author and source are credited, with indications if any changes are made.

creativecommons.org/licenses/by-nc-sa/4.0/
} 


\section{INTRODUCTION}

Among the best examples of symbiosis in the fossil record are endobionts embedded (i.e., bioimmured) by the living tissues of host organisms (Taylor, 1990). Bioclaustrated rugose corals differ from other bioclaustrations as defined by Palmer and Wilson (1988) in having their own skeleton. Skeletonized invertebrates that live in close proximity will often grow into one another to form a fused pair of skeletons, which differs from encrustation in that one skeleton overlaps another (Tapanila, 2008). The full intergrowth of two skeletons provides the most continuous evidence of symbiosis of involved animals (Tapanila, 2008).

The eastern Baltic fauna of rugose corals in the Ordovician is relatively well studied (Kaljo, 1958, 1961, 2004; Neuman, 1969, 1986; Reiman, 1958). The bryozoans are also well-known (Bassler, 1911; Gorjunova, 1992, 1996; Gorjunova and Lavrentjeva, 1993; Lavrentjeva, 1990; Modzalevskaya, 1953; Männil, 1959; Pushkin and Gataulina, 1992), but only a couple of cases of intergrowth between rugosans and bryozoans have been previously reported (Vinn et al., 2016; 2017), and this topic definitely needs further study.

This paper: 1) describes the earliest known intergrowth between rugose corals and a bryozoan host from the early Katian reefs of Estonia, and 2) discusses the paleoecology of this rugosan-bryozoan association.

\section{GEOLOGICAL BACKGROUND AND LOCALITY}

The area, which is Estonia at present (Figure 1 ), was covered by a shallow epicontinental sea in the Ordovician. The Ordovician sequence of northern Estonia is relatively complete with all global stages present and represented mostly by carbonate rocks. Ordovician carbonate rocks are exposed in northern Estonia as a wide belt between Narva River in the east and Hiiumaa Island in the west (Mõtus and Hints, 2007). The drift of Baltica from the southern high latitudes to the tropical realm caused a climatic change (Cocks and Torsvik, 2005; Torsvik and Cocks, 2013). Sedimentation rate of carbonates increased markedly during the climate warming. Due to climatic change deposits characteristic of an arid and tropical climate appeared in the Estonian Ordovician sequence (Mõtus and Hints, 2007). The first signs of tropical climate in the early Katian include the appearance of tabulate corals, stromatoporoids and reefs, but it was not until the Hirnantian that they became prevalent (Mõtus and Hints, 2007).
A large Vasalemma Nordkalk quarry is situated in Vasalemma settlement in northwestern Estonia (Figure 1), west of the Keila-Riisipere railway. Limestones of the Vasalemma Formation are excavated down to the rippled upper surface of the Pääsküla Member of the Kahula Formation (Hints and Miidel, 2008). The Vasalemma Formation (Figure 2) consists of a succession of biodetrital grainstones up to $15 \mathrm{~m}$ thick and contains numerous intercalated reef bodies, composed of bryozoan framestone-bindstone, echinoderm bindstone, receptaculitid-bryozoan-microbial framestone, and tabulate bafflestone. The reef bodies can reach diameters of more than $50 \mathrm{~m}$ (Kröger et al., 2014). Early Katian Guttenberg isotope carbon excursion (GICE) corresponds to the middle and upper part of the Vasalemma Formation (Kröger et al., 2014).

Within the scheme established by Kröger et al. (2014), these reefs developed during a general lowstand, onlapped during transgression, and finally drowned at the latest Oandu/earliest Rakvere stages. The Vasalemma Formation reefs developed during the early phase of the GICE, which is part of a highstand systems tract of a late Sandbian-early Katian depositional cycle (Kröger et al., 2014). The Frognekilen Lowstand Event within the GICE interval ended the reef growth during the latest Keila, early Katian (Figure 2). During this time the reefs were in some places subaerially exposed (Kröger et al., 2014). Afterwards, the dead reefs were rapidly submerged during the Nakkholmen Drowning Event within the Oandu and Rakvere Stages. The reefs grew in a narrow belt of the shelf at the southern part of a north-westward opening shallow local basin (Kröger et al., 2014). The reef flourishing was characteristic to the GICE interval and is probably related to platform wide increase in nutrient levels in the seawater (Kröger et al., 2014).

\section{MATERIAL AND METHODS}

The collections of the Natural History Museum, University of Tartu (TUG) and Department of Geology, Tallinn University of Technology (GIT) contain about 300 bryozoans from the Vasalemma Formation (Keila Regional stage, early Katian). The bryozoans in the collection were searched for the presence of intergrowth with other invertebrates. A single specimen of Orbignyella germana Bassler, 1911, contained embedded rugosans (TUG 1585-10). Two thin sections were made from part of the bryozoan colony containing rugosans for study of internal structures. The thin sections of the rugosan-bryozoan association were 


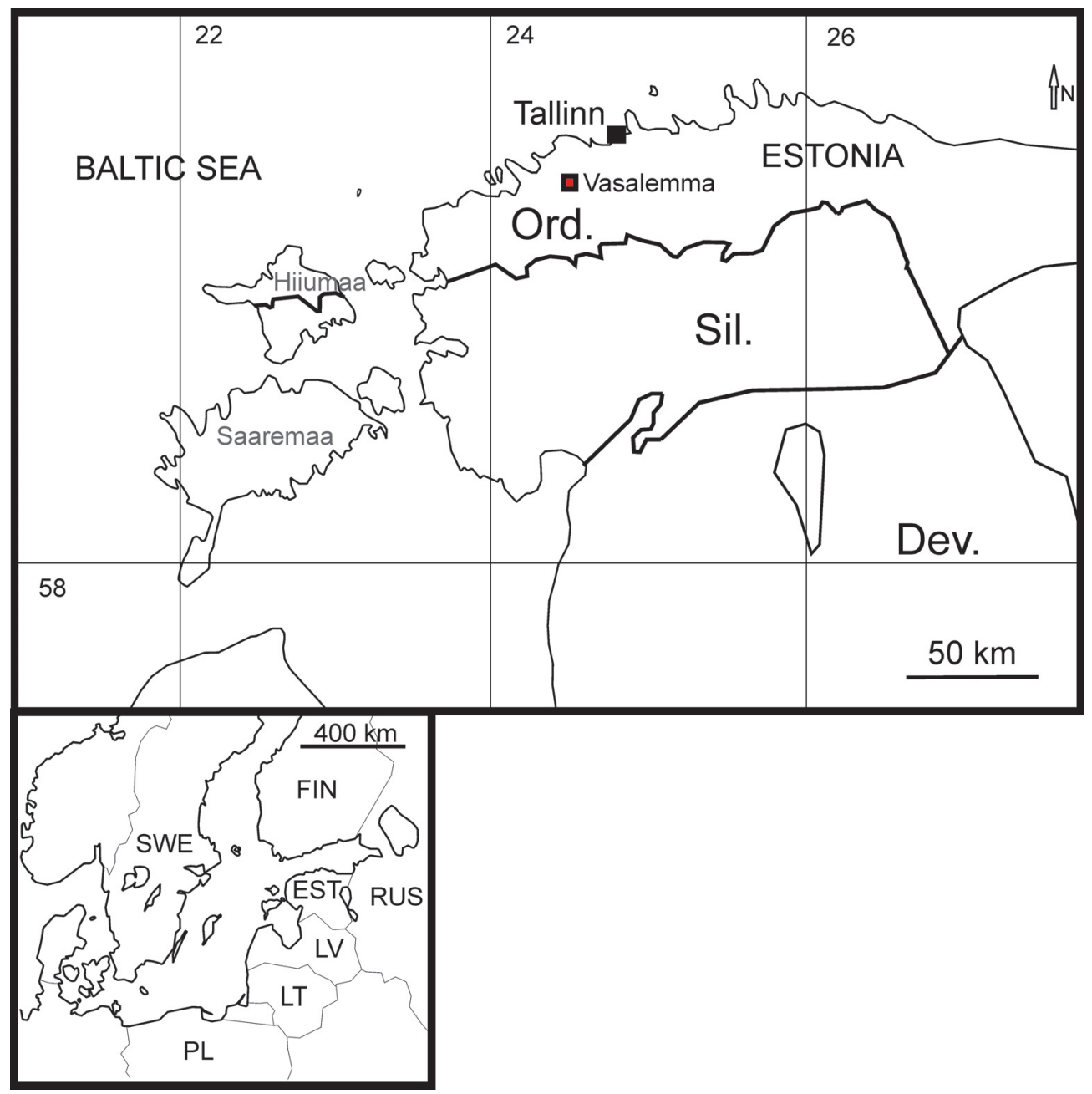

FIGURE 1. Locality map. Location of Vasalemma quarry marked with square.

scanned using a scanner Epson Perfection V750PRO. The dimensions of both rugosans and bryozoan colony were obtained from calibrated photographs.

\section{RESULTS}

A single specimen of Orbignyella germana Bassler, 1911 (Trepostomata, Atactotoechidae) from hundreds of bryozoan specimens shows intergrowth with rugosans Lambelasma carinatum Weyer, 1993 (Stauriida, Lambelasmatidae) (Figure 3). Two specimens of rugose corals that achieved different stages of growth are completely embedded within the bryozoan colony, with exception of their apertures. Diameter of the encrusting bryozoan colony is $22.0 \mathrm{~mm}$. Maximal diameters of rugosans are $13.5 \mathrm{~mm}$ for the large/older specimen and $4.0 \mathrm{~mm}$ for the small/younger one. Larger Lambelasma carinatum specimen is oriented vertically in the center of the Orbignyella colony. The outline of rugosan cross section has an U-shaped deformation that follows the shape of the encrusting bryozoan colony. The size of bryozoan zooids does not decrease near the embedded rugosans. The bryozoan colony does not show any malformations near the embedded rugosans. The walls of embedded rugosans are not thinner or peculiar in any way as compared to typical specimens of $L$. carinatum.

\section{DISCUSSION}

\section{Palaeoecology of the Association}

This association between Lambelasma carinatum and Orbignyella germana most likely occurred due to growth interactions between the rugose corals and the bryozoan colony. The syn vivo nature of this association is supported by the perpendicular orientation of rugosans to the surface of the bryozoan. The growth of the bryozoan 


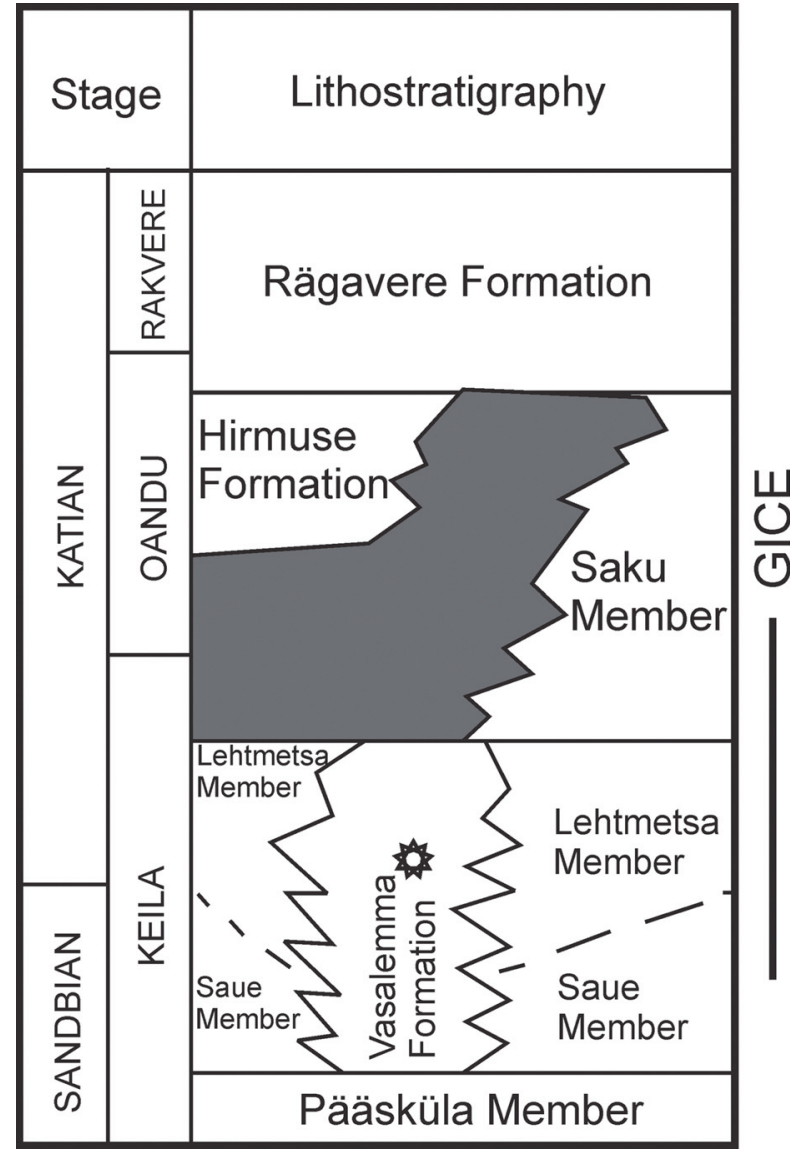

FIGURE 2. Stratigraphy of the Vasalemma Formation (modified after Kröger et al., 2014). Location of samples marked with asterisk.

colony has deformed the shape of larger rugosan cross section. In addition, the embedment of $L$. carinatum by $O$. germana is also restricted to the epithecae, while calices have not been encrusted. An alternative interpretation that bryozoan encrusted dead rugosans is unlikely. It seems impossible or at least very unlikely that living bryozoan could cause malformations in dead rugosan skeleton. Another alternative, that dead bryozoan colony encrusted living or dead rugosan seems equally impossible. According to the low frequency of this association, none of the species was an obligate symbiont of each other, and it is likely that either bryozoans repelled settling rugosans or rugosans used chemical agents to prevent encrustation by bryozoans. It is likely that intergrowth between $L$. carinatum and $O$. germana was purely accidental. However, rugosans may have benefitted from this association in achieving a stable substrate for settlement and growth in shallow and hydrodynamically active waters of the reef environment. They initially cemented to dead parts of the young bryo- zoan colony, and later they became almost completely embedded by subsequent growth of the bryozoan host, which itself used coral as a substrate. In the absence of skeletal evidence indicating damage to the bryozoan, losses are extremely difficult to assess. Regarding benefits, it can be speculated that the presence of the rugose corals provided additional surface to grow on, as well as an advantage in defense against predation. Nevertheless, despite the fact that the benefits may possibly overcame disadvantages, the low occurrence of this association seems to indicate that the association did not represent a significant improvement as compared to non-symbiotic corals and bryozoans of the same species. The walls of embedded rugosans are not thinner or peculiar in any way as compared to non-symbiotic specimens of $L$. carinatum, indicating that the embedded rugosans were not anatomically adapted to a life within bryozoans. Two rugosans occupied some part of the Orbignyella colony feeding surface and may have caused a decrease in the feeding efficiency of the whole colony, but feeding competition between rugosans and their bryozoan host seems unlikely as bryozoans and corals feed on different sources. Corals usually feed on zooplankton, whereas bryozoans consume much smaller phytoplankton, and their feeding methods are also different (Barnes and Hughes, 1999).

\section{Other Examples of Coral-Bryozoan Intergrowth in the Ordovician}

The other known examples of coral-bryozoan intergrowth have been reported from non-reef environments (Vinn et al., 2016, 2017). Several cases of symbiosis between rugose corals and bryozoans are known from the Ordovician of Estonia and North America. The earliest hitherto known example of rugosan-bryozoan intergrowth has been described from the Oandu Regional Stage (early Katian) of northern Estonia (Vinn et al., 2017). It involves relatively large specimens of rugosan Lambelasma sp. that are fully intergrown with the colony of the bryozoan Stigmatella massalis Bassler. This symbiotic association was presumably accidental and similar to the association described here. Rugosans presumably used the host bryozoan as an anchor to stabilize them in hydrodynamically active waters similarly to the here described association. The lack of malformations and decrease in the size of bryozoan zooids near the rugosans is also similar to the association described here. The endobiotic rugose coral symbionts also occur in bryozoans of the Kõrgessaare 

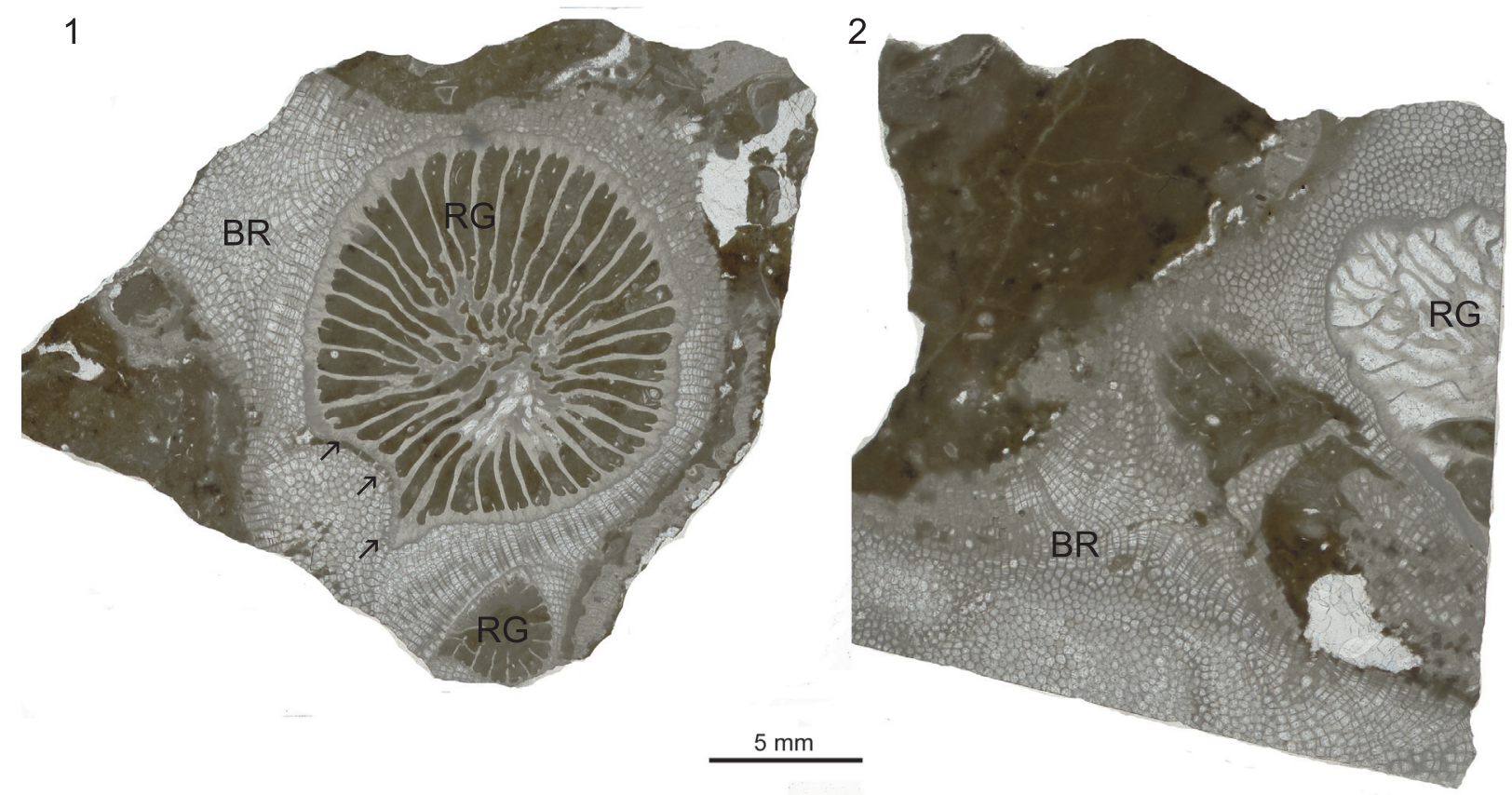

FIGURE 3. 1, A bryozoan colony of Orbignyella germana Bassler, 1911 shows intergrowth with two rugosans Lambelasma carinatum Weyer, 1993 from Vasalemma Formation of northern Estonia (TUG 1585-10); arrows point to skeletal malformation of rugosan, 2, Orbignyella germana Bassler, 1911 with Lambelasma carinatum Weyer, 1993 from Vasalemma Formation of northern Estonia (TUG 1585-10). Abbreviations: RG-rugosan, BR-bryozoan.

Formation (late Katian) of Estonia (Vinn et al., 2016). Multiple rugosans (Bodophyllum sp. and Lambelasma sp.) colonized the cystoporate bryozoan Ceramopora intercellata Bassler, 1911, leaving only their apertures free on the bryozoan growth surface (Vinn et al., 2016). Rugosans had a presumably mutualistic relationship with their bryozoan hosts in the late Katian and symbiosis between rugosans and the bryozoans was facultative (Vinn et al., 2016). This association also involves Lambelasma as the two other rugosanbryozoan associations (see above) reported from the Ordovician of Estonia. Thus, it is likely that Lambelasma may have been especially prone for symbiosis with different genera and species of bryozoans.

Streptelasma divaricans (Nicholson) have been described from the Late Ordovician (Richmondian) bryozoans of the Cincinnati Arch region of USA; larvae of this species presumably frequently settled on living bryozoan colonies (Elias, 1982 , p. 23, pl. 3, fig. 5s). Another rugosan-bryozoan association occurs in the Late Ordovician (Gamachian) of Missouri in the USA where an unidentified species of Streptelasma grew symbiotically with bryozoans. In this association the host bryozoan colony grew around the sides of the epiz- oic corals (McAuley and Elias, 1990, p. 47, pl. 9, figs. 8,9 , pl. 10 , figs. $1-5$ ), which is very similar to the situation in the rugosan-bryozoan association from the Vasalemma Formation of Estonia.

\section{Intergrowth of Invertebrates in Palaeozoic Reefs}

Intergrowth between different invertebrates is common in Palaeozoic reefs and biostromes (Oekentorp, 1969; Kershaw, 1987, 2013; Tapanila, 2005). Accidental intergrowth was presumably favored by high invertebrate population densities in the reefs. The main reason behind the intergrowth of bryozoans and rugosans in the Vasalemma reefs may have also been relatively high population densities and restricted space for the growth. The intergrowth of rugosans with stromatoporoids is especially common in the Silurian biostromes of Baltica (Kershaw, 1987). Intergrown organisms are common in reef stromatoporoids too, but they can occur also in bedded limestone (Kershaw, 2013). Both tabulate and rugose corals are the most abundant, but numerous tube-shaped fossils, probably worms (e.g., Tourneur et al., 1994; Zhen and West, 1997; Zapalski and Hubert, 2011), also occur (Kershaw, 2013). It is possible that reef faunas may have played a key role in the evolution of many 
Palaeozoic symbiotic associations. High spatial competition between different invertebrates in reef environments triggered sporadic interactions that produced embedment of the "infester" by its host. During the stratigraphic record several symbiotic associations may have arisen from these accidental intergrowths in the reef environments. Thus, it is not surprising that true symbiotic associations of rugosans and bryozoans appeared later outside of reefs in the Katian of Estonia.

\section{CONCLUSIONS}

- Earliest known rugosan-bryozoan intergrowth appeared in the early Katian of western Estonia.

- The early rugosan-bryozoan intergrowths were most likely accidental.

- Lambelasma seems to be especially prone for symbiosis with different gen- era and species of bryozoans in the Ordovician.

- Early rugosan-bryozoan intergrowth may have been related to reef facies. It was presumably favored by high invertebrate population densities in the reefs.

\section{ACKNOWLEDGEMENTS}

Financial support to O.V. was provided by Estonian Research Council project IUT20-34. We are grateful to D. Kaljo, Department of Geology, Tallinn University of Technology for identifications of the rugosans and to A. Uffert for making thin sections. We are also grateful to G. Baranov, Institute of Geology, Tallinn University of Technology for digitalization of the specimens. This paper is a contribution to project IGCP 653 "The onset of the Great Ordovician Biodiversity Event." We are thankful for the constructive reviews provided by three anonymous reviewers.

\section{REFERENCES}

Barnes, R.S.K. and Hughes, R.N. 1999. An Introduction to Marine Ecology. Third Edition. Blackwell Science Ltd., Oxford, U.K. https://doi.org/10.1002/9781444313284

Bassler, R.S. 1911. The early Paleozoic Bryozoa of the Baltic provinces. Bulletin of the United States National Museum, 77:1-382. https://doi.org/10.1086/621976

Cocks, L.R.M. and Torsvik, T.H. 2005. Baltica from the late Precambrian to mid-Palaeozoic times: the gain and loss of a terrane's identity. Earth-Science Reviews, 72:39-66. https:// doi.org/10.1016/j.earscirev.2005.04.001

Elias, R.J. 1982. Latest Ordovician solitary rugose corals of eastern North America. Bulletins of American Paleontology, 81:1-116.

Gorjunova, R.V. 1992. Morphology and system of Palaeozoic bryozoans. Trudy Paleontologicheskogo Instituta, 251:1-152. (In Russian)

Gorjunova, R.V. 1996. Phylogeny of the Paleozoic bryozoans. Trudy Paleontologicheskogo Instituta, 267:1-163. (In Russian)

Gorjunova, R.V. and Lavrentjeva, V.D. 1993. Morphology and system of the cryptostome bryozoans. Trudy Paleontologicheskogo Instituta, 257:1-151. (In Russian)

Hints, L. and Miidel, A. 2008. Ripple marks as indicators of Late Ordovician sedimentary environments in Northwest Estonia. Estonian Journal of Earth Sciences, 57:11-22. https:// doi.org/10.3176/earth.2008.1.02

Kaljo, D.L. 1958. Some new and little-known Baltic tetracorals. Trudy Institut Geologii AN ESSR, 3:101-123. (In Russian)

Kaljo, D.L. 1961. Some additional data on the study of Ordovician streptelasmids in Estonia. Trudy Institut Geologii AN ESSR, 6:51-67. (In Russian)

Kaljo, D. 2004. Diversity of late Ordovician rugose corals in Baltoscandia: role of environmental changes and comparison with other areas. Proceedings of the Estonian Academy of Sciences, Geology, 53:233-245.

Kershaw, S. 1987. Stromatoporoid - coral intergrowths in a Silurian biostrome. Lethaia, 20:371382. https://doi.org/10.1111/j.1502-3931.1987.tb02058.x

Kershaw, S. 2013. Palaeozoic stromatoporoid futures: A discussion of their taxonomy, mineralogy and applications in palaeoecology and palaeoenvironmental analysis. Journal of Palaeogeography, 2:163-182. 
Kröger, B., Hints, L., and Lehnert, O. 2014. Age, facies and geometry of the Sandbian/Katian (Upper Ordovician) pelmatozoan-bryozoan-receptaculitid reefs of the Vasalemma Formation, northern Estonia. Facies, 60:963-986. https://doi.org/10.1007/s10347-014-0410-8

Lavrentjeva, V.D. 1990. New genus of cryptostomate bryozoans. Paleontologicheski Zhurnal, 2:127-130. (In Russian)

Männil, R. 1959. Problems of Stratigraphy and Bryozoans from the Ordovician of Estonia. (Candidate of Sciences Thesis) Institute of Geology, Academy of Sciences ESSR, Tallinn, p. 542. (In Russian)

McAuley, R.J. and Elias, R.J. 1990. Latest Ordovician to earliest Silurian solitary rugose corals of the east-Central United States. Bulletins of American Paleontology, 98:1-82.

Modzalevskaya, E.A. 1953. Ordovician Trepostomata from Baltics and their significance in stratigraphy. Trudy VNIGRI, Stratigrafiya i Fauna Ordovika i Silura Zapada Russkoy Platformy, 78:91-167. (In Russian)

Mõtus, M.-A. and Hints, O. 2007. Excursion B2: Lower Paleozoic geology and corals of Estonia, p. 54-55 In Excursion Guidebook, 10th International Symposium on Fossil Cnidaria and Porifera, August 18-22. Institute of Geology at Tallinn University of Technology, Tallinn, Estonia.

Neuman, B. 1969. Upper Ordovician streptelasmatid corals from Scandinavia. University of Uppsala, Geological Institutions Bulletin, New Series, 1:1-73.

Neuman, B. 1986. Rugose corals from the Upper Ordovician erratic boulders of Öland. GFF, 108:349-365. https://doi.org/10.1080/11035898609454725

Oekentorp, K. 1969. Kommensalismus bei Favositiden. Münstersche Forschungen zur Geologie und Paläontologie, 12:165-217.

Palmer, T.J. and Wilson, M.A. 1988. Parasitism of Ordovician bryozoans and the origin of pseudoborings. Palaeontology, 31:939-949.

Pushkin, V.I. and Gataulina, G.M. 1992. A revision of the Early Palaeozoic bryozoans of the Order Cystoporida from E. Eichwald's Collection. Voprosy Paleontologii, 10:88-97.

Reiman, V.M. 1958. Neue Tetrakorallen des baltischent Oberordoviziums und des Llandovery. Trudy Institut Geologii AN ESSR, 2:33-47. (In Russian)

Tapanila, L. 2005. Palaeoecology and diversity of endosymbionts in Palaeozoic marine invertebrates: trace fossil evidence. Lethaia, 38:89-99. https://doi.org/10.1080/ 00241160510013123

Tapanila, L. 2008. Direct evidence of ancient symbiosis using trace fossils, in Kelley, P.H. and Bambach, R.K. (eds.), From Evolution to Geobiology: Research Questions Driving Paleontology at the Start of a New Century: Paleontological Society Short Course, October 4, 2008. Paleontological Society Papers, 14:271-287.

Taylor, P.D. 1990. Preservation of soft-bodied and other organisms by bioimmuration - a review. Palaeontology, 33:1-17.

Torsvik, T.H. and Cocks, L.R.M. 2013. New global palaeogeographical reconstructions for the Early Palaeozoic and their generation. Geological Society Memoirs, London, 38:5-24. https:/ /doi.org/10.1144/M38.2

Tourneur, F., Lachkhem, H., and Mistiaen, B. 1994. Trypanopora conili nov. sp. (Annelida?) from the Couvin Limestone, Eifelian of the southern margin of the Dinant Synclinorium (Belgium). Biological affinities and relationships with its hosts. Mémoires Institut Géologique de I'Université Catholique de Louvain, 35:83-122.

Vinn, O., Ernst, A., and Toom, U. 2016. Earliest symbiotic rugosans in cystoporate bryozoan Ceramopora intercellata Bassler, 1911 from Late Ordovician of Estonia (Baltica).

Palaeogeography, Palaeoclimatology, Palaeoecology, 461:140-144. https://doi.org/10.1016/ j.palaeo.2016.08.016

Vinn, O., Ernst, A., and Toom, U. 2017. Rare rugosan-bryozoan intergrowth from the Late Ordovician of Estonia. Carnets de Géologie, 17:145-151. https://doi.org/10.4267/2042/ 62664

Weyer, D. 1993. Lambelasma carinatum, eine neue Rugose Koralle aus dem Mittel-Ordoviz von Estland. Abhandlungen und Berichte für Naturkunde, 16:70-77.

Zapalski, M.K. and Hubert, B.L.M. 2011. First fossil record of parasitism in Devonian calcareous sponges (stromatoporoids). Parasitology, 138:132-138. https://doi.org/10.1017/ S0031182010001071 
VINN, TOOM, \& ERNST: RUGOSAN BRYOZOAN INTERGROWTH

Zhen, Yong-Yi and West, R.R. 1997. Symbionts in a stromatoporoid chaetetid association from the Middle Devonian Burdekin Basin, north Queensland. Alcheringa, 21:271-280. https:// doi.org/10.1080/03115519708619167 